\title{
Investigation into the mechanism of action of Moringa oleifera for its anti-asthmatic activity
}

\author{
Anita Mehta* and Babita Agrawal \\ Department of Pharmacology, L.M. College of Pharmacy, Ahmedabad - 3800009, India
}

\begin{abstract}
SUMMARY
In the present investigation, we studied the effect of alcoholic extract of Moringa oleifera (M. oleifera) seed kernels on various experimental models of bronchial asthma. Significant $(P<0.05)$ increase in preconvulsion time was observed due to pretreatment with $M$. oleifera when the guinea pigs were exposed to either acetylcholine (Ach) or histamine aerosol. This bronchodilating effect of $M$. oleifera was comparable to ketotifen fumarate. Spasmolytic effect of $M$. oleifera was also observed by dose dependent inhibition of ideal contractions induced by Ach, $5 \mathrm{HT}$, histamine and $\mathrm{BaCl}_{2}$. Alcoholic extract of $M$. oleifera produced significant dose dependent protection by egg albumin and compound 48/80 induced mast cell degranulation. Pretreatment with alcoholic extract of $M$. oleifera also decreased carrageenan induced rat paw edema, which was comparable to that of standard diclofenac sodium. Minimum inhibitory concentration for alcoholic extract of $M$. oleifera was low as compared to cold-water extract and hot water extract when antimicrobial activity was tested against various respiratory pathogens like Escherichia coli (E. coli), Staphylococus aureus (S. aureus) and pseudomonas aeruginosa (P. aeruginosa). Our data suggest that antiasthmatic activity of $M$. oleifera seed kernels may be due to its bronchodilator, anti-inflammatory, mast cell stabilization and antimicrobial activity.
\end{abstract}

Key words: Bronchial asthma; Moringa oleifera; Bronchodilator; Anti-inflammatory; Mast cell stabilization

\section{INTRODUCTION}

Bronchial asthma is a chronic respiratory disorder affecting a large proportion of population throughout the world. The currently used drugs for the treatment of this disease in modern medicine are far from satisfactory as they provide only symptomatic relief, produce several adverse effects and may lose effectiveness on continued use. Muscle tremor and hypokalemia are major adverse effects of $\beta_{2}$ agonists (Haalboom et al., 1985; Nelson, 1986). Theophyline has narrow therapeutic

*Correspondence: Anita Mehta, Department of Pharmacology, L.M. College of Pharmacy, Ahmedabad 3800009, India. E-mail: dranitalmcp@rediffmail.com index and requires monitoring of drug levels (Nasser and Rees, 1993; Stoloff, 1994). Adverse effects of corticosteroids include fluid retention, increased cell mass, increased appetite, weight gain, osteoporosis, capillary fragility, hypertension, peptic ulceration, diabetes, cataract, and phychosis (Dajani et al., 1981). Hence Ayurveda has recommended number of drugs from indigenous plants sources for the treatment of bronchial asthma and other allergic disorders and have been successful in controlling the disease as well. Large numbers of medicinal plant preparations have been reported to possess anti-asthmatic effects.

Moringa oleifera (M. oleifera) is a small or medium sized tree, cultivated throughout India. The tender 
pods are esteemed as a vegetable. Seeds are used as purgative, antipyretic and anti inflammatory (Warrier et al., 1997). The plant possesses antimicrobial activity (Caceres et al., 1991), while the seeds reportedly have antispasmodic, anti inflammatory and diuretic activity (Caceres et al., 1992). Its leaves and fruits are edible, rich in ascorbic acid. The plant is also reported to elicit good clinical response in children suffering from upper respiratory tract infection and skin infection. It has been reported that alkaloid from the plant closely resembles ephedrine in action and useful in treatment of asthma. Alkaloid Moringine relaxes bronchioles (Kirtikar and Basu, 1975). In the present study, we have investigated the anti-asthmatic potential of M. oleifera on various experimental models like Bronchodilating, mast cell stabilizing, anti inflammatory and antimicrobial activity.

\section{MATERIALS AND METHODS}

\section{Plant material}

Seed kernels of $M$. oleifera were purchased from the local market of Ahmedabad and were identified and authenticated by Dept. of pharmacognosy, L.M. College of Pharmacy, Ahmedabad, India. A voucher specimen was deposited at the Dept. of pharmacognosy, Ahmedabad. The coarse powder $(500 \mathrm{~g})$ of the dried seed kernels was defatted using petrol ether and then it was exhaustively extracted using $95 \%$ ethanol $(2,000 \mathrm{ml})$ in a soxhlet extractor. Cold aqueous extract of $M$. oleifera was prepared by extracting 1 part of seed kernels with 10 parts of water for $2 \mathrm{~h}$ without heating, while hot aqueous extract was prepared by heating the seed kernels with water. The extracts were concentrated under reduced pressure to yield a syrupy mass and stored in air tight container in cool place and used throughout the project.

\section{Animals}

All animals were housed at ambient temperature $\left(22 \pm 1^{\circ} \mathrm{C}\right)$, relative humidity $(55 \pm 5 \%)$ and $12 / 12 \mathrm{~h}$ light/dark cycle. Animals had access to standard pallet diet and water given ad libitum. The protocol of the experiment was approved by the institutional animal ethical committee as per the guidance of the Committee for the purpose of Control and Supervision of Experiments on Animals (CPCSEA), Ministry of Social Justice and Empowerment, Government of India.

\section{Studies on Acetylcholine and Histamine induced bronchospasm in guinea pigs}

Guinea pigs of either sex weighing 350 - $500 \mathrm{~g}$ were selected and randomly divided into six groups each containing six animals. The drugs were administered orally in $0.5 \%$ sodium carboxymethyl cellulose (CMC). The single dose treatments were given one and half an hour before the study. The following schedule of treatment was administered:

Group I: 0.5\% CMC (control)

Group II: Ketotifen $(1 \mathrm{mg} / \mathrm{kg})$ (standard)

Group III: Alcoholic extract of M. oleifera $(100 \mathrm{mg} / \mathrm{kg})$

Group IV: Alcoholic extract of M. oleifera $(200 \mathrm{mg} / \mathrm{kg})$

Later the animals were exposed to an aerosol of $0.25 \%$ histamine and time for preconvulsion state was noted for each animal (Sheth et al., 1972). After about 15 days of wash out period, the same animals were given the above treatments and time for preconvulsion state was noted for $0.5 \%$ acetylcholine bromide aerosol spray.

\section{Studies on isolated Guinea pig ileum}

Overnight fasted guinea pigs of either sex weighing 400 - $600 \mathrm{~g}$ were sacrificed using cervical dislocation method. Ileum was quickly dissected out and mounted in an organ bath maintained at $37 \pm 1^{\circ} \mathrm{C}$ and containing $20 \mathrm{ml}$ Tyrode's solution under basal tension of $500 \mathrm{mg}$. The composition of solution in $\mathrm{mM}$ was $\mathrm{NaCl}, 137 ; \mathrm{CaCl}_{2}, 1.8 ; \mathrm{KCl}$, 2.7; glucose, 5.55; $\mathrm{NaHCO}_{3}, 11.9 ; \mathrm{MgCl}_{2}, 1 ; \mathrm{NaH}_{2} \mathrm{PO}_{4}$, 0.4. The solution was continuously bubbled with air. The responses to drug were recorded on a Student 
physiograph (BioDevices) using isotonic transducer, which exerted a basal tension equivalent to $500 \mathrm{mg}$ load on tissue. The issue was allowed to equilibrate for $30 \mathrm{~min}$, during which, the bathing solution was changed at every $10 \mathrm{~min}$. The contractile responses of ileum to various agonists (Acetylcholine, histamine, 5- $\mathrm{HT}$ and $\mathrm{BaCl}_{2}$ ) were recorded in presence and absence of alcoholic extract of $M$. oleifera.

\section{Studies on compound $48 / 80$ and egg albumin} induced rat peritoneal mast cell degranulation

Normal saline containing 5 units $/ \mathrm{ml}$ of heparin was injected in the peritoneal cavity of male rats lightly anaesthetized with ether. After a gentle abdominal message, the peritoneal fluid containing mast cells was collected in centrifuge tubes placed over ice. Peritoneal fluid of 4 - 5 rats was collected and pooled and centrifuged at 2,000 rpm for $5 \mathrm{~min}$. Supernatant solution was discarded and the cells were washed twice with saline and resuspended in $1 \mathrm{ml}$ of saline.

$0.1 \mathrm{ml}$ of the peritoneal cell suspension was transferred to 6 test tubes and was treated as follows.

Test tube no. $1 \& 2$ - Saline

Test tube no. $3-0.1 \mathrm{ml}$ of $0.5 \mathrm{mg} / \mathrm{ml}$ alcoholic extract of M. oleifera in Saline

Test tube no. $4-0.1 \mathrm{ml}$ of $1.0 \mathrm{mg} / \mathrm{ml}$ alcoholic extract of $M$. oleifera in Saline

Test tube no. $5-0.1 \mathrm{ml}$ of $2.0 \mathrm{mg} / \mathrm{ml}$ alcoholic extract of $M$. oleifera in Saline

Test tube no. $6-0.1 \mathrm{ml}$ of $10 \mu \mathrm{g} / \mathrm{ml}$ of Ketotifen fumarate

Each test tube was incubated for $15 \mathrm{~min}$ at $37^{\circ} \mathrm{C}$ and then Compound $48 / 80(0.1 \mathrm{ml}, 10 \mu \mathrm{g} / \mathrm{ml})$ was added to each test tube except test tube no. 1 . After further incubation for $10 \mathrm{~min}$. at $37^{\circ} \mathrm{C}$, the cells were stained with $0.1 \%$ toluidine blue solution made in distilled water and examined under the high power of light microscope. Percent protection of the mast cells in the control group and the treated groups were calculated by counting the number of degranulated mast cells from total of atleast 100 mast cells counted.

In another study, rats were sensitized by administering three doses of $350 \mu \mathrm{g}$ of egg albumin adsorbed on $60 \mathrm{mg}$ of aluminum hydroxide gel, the doses being given on the first, third and fifth day subcutaneously. The mast cells were collected on the tenth day of sensitization. The study was conducted in the same manner as above and the sensitized cells were degranulated using egg albumin $(1 \mathrm{mg} / \mathrm{ml})$. Percent protection of the mast cells in the control group and the treated groups were calculated by counting the number of degranulated mast cells from total of atleast 100 mast cells counted. Control group is consisted of positive control group in which egg albumin was added without addition of test agent and a negative control group in which neither egg albumin nor the test agent was added to correct for spontaneous degranulation of mast cells without any degranulating agent.

\section{Anti inflammatory study \\ Carrageenan induced rat paw edema}

Albino rats of either sex weighing 200 - $250 \mathrm{~g}$ were divided in 4 groups of 6 animals each. The following schedule of treatment was administered:

Group I: $0.5 \%$ CMC

Group II: Diclofenac sodium (20 mg/kg p.o.)

Group III: Alcoholic extract of M. oleifera $(200 \mathrm{mg} / \mathrm{kg}$ p.o.) in $0.5 \% \mathrm{CMC}$

Group IV: Alcoholic extract of M. oleifera (400 mg/ kg p.o.) in $0.5 \%$ CMC

Animals were treated with drugs and subsequently $1 \mathrm{~h}$ after treatment; $0.1 \mathrm{ml}$ of $1 \%$ carrageenan was injected subcutaneously into the planter region of right hind paw to induce edema. The paw volume was measured initially and at 1,3 and $5 \mathrm{~h}$ after carrageenan injection using plethysmographic method of Harris and Spencer (1962). Percentage increase in paw volume from baseline was calculated and compared with control. 


\section{Anti microbial studies}

The in vitro antimicrobial activity of the M. oleifera was studied by broth dilution method and minimum inhibitory concentration was found out. Cold aqueous extract, hot aqueous extract and the alcoholic extract were prepared from the seeds of $M$. oleifera. These extracts at different concentrations $(5-100 \mathrm{mg} / \mathrm{ml})$ were tested against the organisms Escherichia coli, Staphylococus aureus and pseudomonas aeruginosa.

Statistical analysis: All the results were tested for significance using Student's $t$-test at the probability level of $95 \%$.

\section{RESULTS}

Effect of M. oleifera on Ach and Histamine induced bronchospasm in guinea pigs

Significant increase in preconvulsion time was observed due to pretreatment with M. oleifera (100 $\mathrm{mg} / \mathrm{kg}$ and $200 \mathrm{mg} / \mathrm{kg}$ ) when the guinea pigs were exposed to either acetylcholine $(0.5 \%)$ or histamine $(0.25 \%)$ aerosol. The increase in preconvulsion time was comparable to that of Ketotifen $(1 \mathrm{mg} /$ kg) (Table 1).

Effect of M. oleifera on agonists induced contractions of guinea pig ileum

Alcoholic extract of M. oleifera ( $50-150 \mu \mathrm{g} / \mathrm{ml})$ dose dependently inhibited ileal contractions induced by histamine $\left(3.84 \times 10^{-4} \mathrm{mM}\right)$, Ach $\left(4.12 \times 10^{-5} \mathrm{mM}\right)$, 5HT $\left(5.67 \times 10^{-5} \mathrm{mM}\right)$ and $\mathrm{BaCl}_{2}\left(2.4 \times 10^{-3} \mathrm{mM}\right)$ (Table 2).

Compound 48/80 induced rat mast cell degranulation Compound 48/80 (10 $\mu \mathrm{g} / \mathrm{ml})$ produced significant disruption of mast cells which was significantly inhibited in a dose-dependent manner by pretreatment with the alcoholic extract of $M$. oleifera

Table 1. Effect of M. oleifera on Ach and Histamine induced bronchospasm in guinea pigs

\begin{tabular}{clcc}
\hline \multirow{2}{*}{ Sr. no. } & \multirow{2}{*}{ Treatment } & \multicolumn{2}{c}{ \% Increase in preconvulsion time } \\
\cline { 3 - 4 } & & Acetylcholine & Histamine \\
\hline 1 & M. oleifera $(100 \mathrm{mg} / \mathrm{kg}$ p.o. $)$ & $41.90 \pm 7.94^{*}$ & $27.85 \pm 3.96^{*+*+*}$ \\
2 & M. oleifera $(200 \mathrm{mg} / \mathrm{kg}$ p.o. $)$ & $56.31 \pm 3.11^{*+*}$ & $36.13 \pm 3.68^{*+*+*}$ \\
3 & Ketotifen fumarate $(1 \mathrm{mg} / \mathrm{kg}$ p.o. $)$ & $28.80 \pm 2.77$ & $33.92 \pm 3.12$ \\
\hline
\end{tabular}

*Significantly different from baseline (Student's paired $t$ test) $(\mathrm{n}=6) .{ }^{*} P<0.05,{ }^{*+* k *} \mathrm{P}<0.001$.

Table 2. Effect of $M$. oleifera on agonists induced contractions of guinea pig ileum

\begin{tabular}{ccccc}
\hline $\begin{array}{c}\text { Conc. of M.oleifera } \\
\text { extract }(\mathrm{mg} / \mathrm{ml})\end{array}$ & $\begin{array}{c}\text { \% Inhibition of Hista- } \\
\text { mine contractions }\end{array}$ & $\begin{array}{c}\text { \% Inhibition } \\
\text { of Ach contractions }\end{array}$ & $\begin{array}{c}\text { \% Inhibition of } 5 \mathrm{HT} \text { \% } \\
\text { contractions }\end{array}$ & $\begin{array}{c}\text { Inhibition of } \mathrm{BaCl}_{2} \\
\text { contractions }\end{array}$ \\
\hline 50 & $48.718 \pm 1.16$ & $16.412 \pm 0.89$ & $28.306 \pm 0.65$ & $48.72 \pm 2.05$ \\
100 & $61.88 \pm 1.19$ & $27.27 \pm 1.18$ & $58.692 \pm 0.44$ & $63.385 \pm 2.25$ \\
150 & $65.4821 \pm 1.24$ & $38.448 \pm 1.09$ & $72.216 \pm 0.47$ & $80.74 \pm 0.99$ \\
\hline
\end{tabular}

Table 3. Effect of $M$. oleifera extract on compound 48/80 induced rat peritoneal mast cell degranulation

\begin{tabular}{cccc}
\hline Treatment & Concentration $(\mathrm{mg} / \mathrm{ml})$ & \% Mast cells degranulation \pm S.E.M. & \% Inhibition of degranulation \\
\hline Negative Control & - & $1.19 \pm 0.96$ & - \\
Positive Control & - & $74.82 \pm 0.467$ & - \\
M. oleifera extract & 0.5 & $33.37 \pm 1.338^{*+*}$ & 56.29 \\
M. oleifera extract & 1.0 & $28.71 \pm 0.131^{*+*}$ & 62.62 \\
M. oleifera extract & 2.0 & $24.15 \pm 0.432^{*+*}$ & 68.82 \\
Ketotifen fumarate & $10 \mu \mathrm{g} / \mathrm{ml}$ & $18.02 \pm 0.343^{*+*}$ & 77.14 \\
\hline
\end{tabular}

$\mathrm{N}=6$ in each group. *Significantly different from control. ${ }^{* *} P<0.01$ (Student's $t$ test). 
Table 4. Effect of M. oleifera extract on Egg Albumin induced rat peritoneal mast cell degranulation

\begin{tabular}{cccc}
\hline Treatment & $\begin{array}{c}\text { Concentration } \\
(\mathrm{mg} / \mathrm{ml})\end{array}$ & $\begin{array}{c}\text { \% Mast cells } \\
\text { degranulation } \pm \text { S.E.M. }\end{array}$ & $\begin{array}{c}\text { \% Inhibition of } \\
\text { Degranulation }\end{array}$ \\
\hline Negative Control & - & $1.19 \pm 0.96$ & - \\
Positive Control & - & $79.56 \pm 1.126$ & - \\
M. oleifera Extract & 0.5 & $29.95 \pm 0.334^{* *}$ & 63.30 \\
M. oleifera Extract & 1.0 & $27.77 \pm 0.447^{* *}$ & 66.09 \\
M. oleifera Extract & 2.0 & $22.68 \pm 0.317^{* *}$ & 72.58 \\
Ketotifen fumarate & 0.01 & $17.01 \pm 0.463^{* *}$ & 79.81 \\
\hline
\end{tabular}

$\mathrm{N}=6$ in each group. ${ }^{*}$ Significantly different from control. ${ }^{* *} P<0.01$ (Student's $t$ test).

Table 5. Effect of M. oleifera on Carageenan induced rat paw edema

\begin{tabular}{lcccc}
\hline \multirow{2}{*}{ Treatment } & Dose & \multicolumn{2}{c}{ \% Increase volume of paw (\% anti-inflammatory effect) } \\
\cline { 3 - 5 } & $(\mathrm{mg} / \mathrm{kg})$ & \multicolumn{1}{c}{$1 \mathrm{~h}$} & $3 \mathrm{~h}$ & $5 \mathrm{~h}$ \\
\hline Control & & $7.607 \pm 1.03$ & $20.522 \pm 1.579$ & $27.66 \pm 1.685$ \\
M. oleifera & 200 & $6.978 \pm 0.097(8.27)$ & $17.96 \pm 0.787^{* * *}(12.48)$ & $16.87 \pm 0.96^{* *}(39.01)$ \\
M. oleifera & 400 & $5.195 \pm 0.453(31.7)$ & $9.214 \pm 1.328^{*}(55.1)$ & $6.40 \pm 0.429^{* *}(76.87)$ \\
Diclofenac sodium & 20 & $2.577 \pm 0.461(66.11)$ & $8.175 \pm 1.17^{*}(60.16)$ & $4.58 \pm 0.819^{* *}(83.43)$ \\
\hline
\end{tabular}

Significantly different from control. ${ }^{*} P<0.05,{ }^{* *} P<0.01,{ }^{* *} P<0.001$ (Student's $t$ test).

Table 6. Anti microbial study of M. oleifera

\begin{tabular}{clccc}
\hline \multirow{2}{*}{ Sr. No. } & \multicolumn{2}{c}{ Organism } & \multicolumn{2}{c}{ Minimum Inhibitory concentration $(\mathrm{mg} / \mathrm{ml})$} \\
\cline { 3 - 5 } & & Cold water extract & Hot water extract & Alcoholic extract \\
\hline 1 & E-coli ATCC-25922 & 20 & 100 & 10 \\
2 & P. aeruginosa ATCC-27853 & 20 & - & - \\
3 & S. aureus ATCC-25923 & 10 & 50 & 50 \\
\hline
\end{tabular}

in concentrations of $0.5-2.0 \mathrm{mg} / \mathrm{ml}$ (Table 3). Egg Albumin (1 $\mathrm{mg} / \mathrm{ml})$ induced rat mast cell degranulation was significantly inhibited by pretreatment of the animals with the alcoholic extract of $M$. oleifera in concentrations of $0.5-2.0$ $\mathrm{mg} / \mathrm{ml}$. The protection was comparable to the reference standard Ketotifen $(10 \mu \mathrm{g} / \mathrm{ml})$ (Table 4$)$.

Effect of $M$. oleifera on Carrageenan induced rat paw edema

Alcoholic extract of M. oleifera at the dose of 200 $\mathrm{mg} / \mathrm{kg}$ and $400 \mathrm{mg} / \mathrm{kg}$ decreased rat paw edema (76.87\% reduction in edema volume), which was comparable to that of standard Diclofenac Sodium $20 \mathrm{mg} / \mathrm{kg}$ (83.43\% reduction in edema volume) (Table 5).

\section{Anti microbial study}

Minimum Inhibitory Concentration for alcoholic extract was low as compared to cold-water extract and hot water extract of $M$. oleifera. Hot water extract and alcoholic extract were ineffective against $P$. aeruginosa. Cold-water extract of $M$. oleifera was found to be more active against Gram-positive bacteria, while alcoholic extract was found to be active against Gram-negative bacteria (Table 6).

\section{DISCUSSION}

The results from our earlier clinical study on $M$. oleifera suggest that, there was appreciable decrease in severity of symptoms of asthma and also simultaneously improvement in lung function 
parameters. Also, none of the patients showed change in any general parameters or any adverse effect suggest safety of drug in dose used. Considering the availability along with convenience and efficacy in oral administration, the drug offers a good future in treatment of asthma. Since bronchodilators, mediator release inhibitors, antiinflammatory drugs and anti-microbials are the different classes of drugs used conventionally in the treatment of bronchial asthma; various animal models and experimental protocols were used in the present study to determine the mechanisms of anti-asthmatic activity of M. oleifera.

Bronchial asthma is characterized by increased airway reactivity to spasmogens (Cockcroft, 1983). An initial event in asthma appears to be the release of inflammatory mediators (e.g. Histamine, Tryptase, Leukotrienes and prostaglandins). Some of these mediators directly cause acute bronchoconstriction, airway hyperresponsiveness and bronchial airway inflammation. Spasmolytic drugs like beta adrenergic agonists, xanthine derivatives and anticholinergics relax the airway smooth muscles and are used as quick relief medications in acute asthmatic attacks. Beta adrenergic agonists promote bronchodilation by direct stimulation of beta adrenergic receptors in the airway smooth muscle, that lead to relaxation of bronchial smooth muscle by rapid decrease in airway resistance in vivo. Specific $\beta 2$ agonists like salbutamol, salmeterol etc. are used since long for symptomatic relief in asthma. In present study, significant increase in preconvulsion time was observed due to pretreatment with M. oleifera, when the guinea pigs were exposed to either Ach or histamine aerosol. This bronchodilating effect of M. oleifera was comparable to ketotifen. It has been reported that Albizzia lebbeck (Tripathi and Das, 1977) and Ocimum sanctum (Singh and Agarwal, 1991), which are well known anti-asthmatic herbal drugs have similar mechanism of action. Spasmolytic effect of M. oleifera was also evaluated by observing the effect of its alcoholic extract on histamine, Ach, $5 \mathrm{HT}$ and $\mathrm{BaCl}_{2}$ induced ileal contractions. $M$. oleifera produced dose dependent inhibition of ileal contractions induced by histamine, Ach, 5- HT and $\mathrm{BaCl}_{2}$. These indicate that $M$. oleifera has a nonspecific spasmolytic activity on smooth muscle. Tylophora asthmatica has also been shown to possess non-specific spasmolytic activity (Harnath and Shyamalakumari, 1975). These effects of M. oleifera correlate with our earlier results of improvement in the symptoms and lung function parameters of asthmatic subjects.

In addition to bronchodilating activity, a significant number of therapeutic approaches for bronchial asthma have been designed based on the antagonism of specific mediators released from mast cells. Mast cell degranulation is important in the initiation of immediate responses following exposure to allergens. Degranulated cells liberate mediators of inflammation such as histamine, leukotrienes, platelet activating factors and chemotactic factors for eosinophils, neutrophils etc. from mast cells (Cushing, 1957; Bellanti, 1971). They play a significant role in airway inflammatory response such as airway eosinophilia, late asthmatic response and airway hyperresponsiveness as well as in immediate hypersensitivity reaction like bronchial contraction. Degranulation of mast cells has been taken as the criteria of positive anaphylaxis. Ketotifen fumarate, a well-known mast cell stabilizer, reduces synthesis of prostaglandins $\mathrm{E}_{2}$, thromboxane $\mathrm{A}_{2}$, leukotriene $\mathrm{C}_{4}$ and $\mathrm{B}_{4}$. It also inhibits release of histamine, serotonin and other inflammatory mediators from mast cells. Simultaneously it blocks $\mathrm{H}_{1}$ receptors. Khellin is a compound isolated from Ammi visnaga and its structural analogue furanochromone khellin. Cromolyn sodium, which is developed from the structural modification of Khellin (Cox et al., 1970) is the mast cell stabilizer used in the treatment of mild to moderate asthma. Adhatoda vasica, Albizzia lebbeck, Coleus forskohlii, Tylophora asthmatica etc. are several well known drugs from indigenous plant sources used in asthma and have been reported to have mast cell stabilizing activity (Tripathi et al., 1979; Atal, 1980; Geetha et al., 1981; 
Marone et al., 1987). A significant protection of rat peritoneal mast cells from disruption by antigen and compound $48 / 80$ by alcoholic extract of $M$. oleifera points towards its ability to interfere the release and/or synthesis of mediators of inflammation, indicating its mast cell stabilizing activity.

Further, airway inflammation has been demonstrated in all forms of asthma. Even in mild asthma, there is an inflammatory response involving infiltration, particularly with activated eosinophils and lymphocytes, with neutrophils and mast cells. The degree of bronchial hyperresponsiveness and airway obstruction is closely linked to the extent of inflammation (Bousquet et al., 2000). Anti-inflammatory drugs suppress the inflammatory response by inhibiting infiltration and activation of inflammatory cells as well as their synthesis, or release of mediators and the effects of inflammatory mediators. The carrageenan induced paw edema model in rats is known to be sensitive to cycloxygenase inhibitors. Alcoholic extract of $M$. oleifera possess potent antiinflammatory activity, which was comparable to that of standard Diclofenac Sodium. Since, serotonin, histamine and prostaglandins are the common mediators of both bronchial asthma and inflammation, the beneficial effect of alcoholic extract of $M$. oleifera could be due to inhibition of their release possibly due to inhibition of the enzyme cycloxygenase leading to inhibition of prostaglandin synthesis.

In India, the patients with bronchial asthma are commonly prescribed with antibiotics. It has been reported that $78.4 \%$ of asthmatic patients receive different antibiotics (Goyal and Patel, 2003). On further investigation, it has been reported that these patients are resistant to many antibiotics prescribed (Goyal and Patel, 2003). It is possible that these patients are suffering from bronchial infection but have been diagnosed as asthmatic patients because of their symptoms like breathlessness. In allopathy, multidrug approach is there where patients receive bronchodilators, corticosteroids along with antibiotics. Sometimes, nonpathogenic bacteria accumulate due to the bronchial obstruction and plugging, causing serious infection. Plants produce a range of chemical substance to protect themselves from the attack of various pathogenic microorganisms. The substances that can either inhibit the growth of microorganisms or kill them are considered for developing new drugs for various infectious diseases. Use of these medicinal plants can substitute antibiotics to treat associated infection. In the present study, $M$. oleifera possess good Antimicrobial activity when tested against various respiratory pathogens that can be used to control respiratory complications.

In conclusion our data suggests that M. oleifera seed kernels have potential anti-asthmatic activity that may be due to its bronchodilator, mast cell stabilization, anti-inflammatory and anti microbial property. Further study is ongoing to characterize the active principles of the ethanolic extract which are responsible for antiasthmatic activity.

\section{REFERENCES}

Atal CK. (1980) Chemistry and Pharmacology of Vasicine: A new oxyoxic and abortifacient, RRL, Jammu, India. 1980.

Bellanti JA. (1971) Mechanism of Tissue Injury produced by Immunologic Reactions In Immunology, Asian Edn: p. 184, W.B. Saunder Co. Tokyo.

Bousquet J, Jeffery PK, Busse WW. (2000) Asthma: From bronchoconstriction to airways inflammation and remodeling. Am. J. Respir. Crit. Care Med. 161, 1749-1745.

Caceres A, Cebreva O, Morales O, Miollinedo P, Mendia P. (1991) Pharmacological properties of $M$. oleifera 1: Preliminary screening for antimicrobial activity. J. Ethnopharmacol. 33, 213-216.

Caceres A, Saravia A, Rizzo S, Zabala L, De-Leon E, Nave F. (1992) Pharmacological properties of M. oleifera

2: Screening for antispasmodic, aniinflammatory and diuretic activity. J. Ethnopharmacol. 36, 233-237.

Cockcroft DW. (1983) Mechanism of perennial allergic asthma. Lancet 2, 253-256.

Cox JSG, Beach JE, Blair AM, Clarke AJ, King J, Lee TB. (1970) Disodium chromoglycate (Intal). Adv. 
Drug Res. 5, 115-196.

Cushing JE, Campbell DH. (1957) Manifestations of Antigen Antibody Reactions In Principals of Immunology. p. 278, McGrew-Hill Book Co. Inc. NY.

Dajani BM, Sliman NA, Shubair KS, Hamzeh YS. (1981) Bronchospasm caused by intravenous hydrocortisone sodium succinate (Solu-Cortef") in asprin-sensitive asthmatics. J. Allergy Clin. Immunol. 68, 201-206.

Geetha VS, Viswanathan S, Kameswaran L. (1981) Comparison of total alkaloids of Tylophora indica and disodium cromoglycate on mast cell stabilization. Indian J. Pharm. 13, 199-201.

Goyal RK, Patel NJ. (2003) Pharmacovigilance for respiratory disorders in N. Gujarat. In: Pharmacovigilance: an update. p. 190-201.

Haalboom JRE, Deenstra A, Stuyvenberg A. (1985) Hypokalaemia induced by inhalation of Fenoterol. Lancet 1, 1125-1127.

Haranath PSRK, Shyamalakumari S. (1975) Experimental study on the mode of action of Tylophora asthmatica in bronchial asthma. Indian J. Med. Res. 63, 661-670.

Harris JM, Spencer PSJ. (1962) A modified plethysmographic apparatus for recording volume changes in rat paw. J. Pharm. Pharmacol. 14, 464-466.

Kirtikar KR, Basu BD. (1975) Indian medicinal plants. (M/s Bishen Singh, Mahendra Pal Singh, New Cannaught Place, Dehradun). Vol. 1, Ed. 2, 676-683.
Marone G, Columbo M, Triggiani M, Cirillo R, Genovese A, Formisano S. (1987) Inhibition of IgE mediated release of histamine and peptide leukotriene from human basophils and mast cells by forskolin. Biochem. Pharmacol. 36, 13-20.

Nasser SS, Rees PJ. (1993) Theophylline. Current thoughts on the risk and benefits of its use in asthma. Drug Saf. 8, 12-18.

Nelson HS. (1986) Adrenergic therapy of bronchial asthma. J. Allergy Clin. Immunol. 77, 771-785.

Sheth UK, Dadkar NK, Kamat NG. (1972) Selected topics in experimental pharmacology. Kohari book depot. Bombay. 5, 63.

Singh S, Agrawal SS. (1991) Anti asthmatic and antiinflammatory activity of Ocimum sanctum. Indian J. Pharmacol. 29, 306-310.

Stoloff SW. (1994) The changing role of theophylline in pediatric asthma. Am. Fam. Physician 49, 839-844.

Tripathi RM, Das PK. (1977) Studies on anti-asthmatic and anti-anaphylactic activity of Albizzia lebbeck. Indian J. Pharmacol. 9, 189-194.

Tripathi RM, Sen PC, Das PK. (1979) Studies on the mechanism of action of Albizzia lebbeck, an Indian indigenous drug used in the treatment of atopic allergy. J. Ethnopharmacol. 1, 385-396.

Warrier PK, Nambiar VPK, Ramankutty C. (1997) Compendium of Indian medicinal plants. 4, 59 . 